\title{
Etsuko’s Pursuit of Identity: An Interpretation of A Pale View of Hills from the Perspective of Spatial Criticism
}

\author{
HU Sheng-hao \\ School of Foreign Languages, Central China Normal University, Wuhan, China
}

\begin{abstract}
On the basis of Etsuko's memory, A Pale View of Hills, a masterpiece of Kazuo Ishiguro, narrates Etsuko's life experiences and her identity construction. The paper analyses the novel from the perspective of spatial criticism proposed by Edward Soja and explores the three-dimensional spaces constructed in the novel in order to explore Etsuko's attempts to leave the marginal space and analyse her pursuit of identity. The paper comes to the conclusion that by constructing Thirdspace open to all cultures, Etsuko eliminates the dichotomy between Firstspace and Secondspace and embraces her hybrid identity.
\end{abstract}

Keywords: Kazuo Ishiguro, A Pale View of Hills, spatial criticism

\section{Introduction}

A Pale View of Hills (1982) is one of the masterpieces written by Kazuo Ishiguro (1954- ), a Japanese-born British writer, who won the Nobel Prize for Literature in 2017. The novel, based upon Etsuko's memory, narrates Etsuko's life experiences. After the Second World War, Etsuko's hometown, Nagasaki, is reduced to ruins. In order to lead a better life, Etsuko attempts to emigrate from Japan to a foreign country, but she ignores her daughter's happiness. At last, she successfully immigrates to Britain, but her daughter Keiko commits suicide.

Since its publication in 1982, the novel has attracted the attention of a great number of scholars. Brian Shaffer analyses the style of the novel and considers it "subtly ironic, tightly structured, stylistic restrained yet emotionally and psychologically explosive" (Shaffer, 1998, p. 12). Molino approaches the novel from the perspective of trauma and argues that it reflects "individual experiences locked in a complex neurological and psychological struggle of traumatized memory” (Molino, 2012, p. 334). In China, there are also many scholars who analyse the novel from diverse perspectives. For example, Zheng Yajie explores war trauma writing and generational differences revealed in the novel, and Teng Aiyun analyses the novel from the perspective of ethical literary criticism. To sum up, scholars at home and abroad tend to interpret A Pale View of Hills from the perspectives of trauma and memory, and the theme and the style of the novel constitute the focus of their researches.

It is noteworthy that Etsuko's attempts to emigrate from Japan manifest her desire for an independent identity, and an analysis of the novel from the perspective of spatial criticism will demonstrate Etsuko's attempts

HU Sheng-hao, Master Candidate, School of Foreign Languages, Central China Normal University, Wuhan, China. 
to situate herself in the central space of the society and build her own identity. It seems that spatial criticism can shed light upon Etsuko's pursuit of identity and help to approach the novel from a new point of view.

Time and space are two important elements of human life, and therefore there is no doubt that scholars should pay equal attention to both time and space. However, the significance of space has been neglected for a long time, and scholars have attached overdue importance to time. Against the backdrop, a number of scholars begin to explore the spatiality of human life in the late 20th century. For example, Henri Lefebvre, a French scholar, puts forth three concepts, namely spatial practice, representation of space and representational space, in his work The Production of Space in order to connect "historicality, sociality, and spatiality in a strategically balanced and transdisciplinary "triple dialectic"” (Soja, 1996, p. 6). It is on the basis of the theory proposed by Lefebvre that Edward Soja proposes his theory of Thirdspace in his book Thirdspace: Journeys to Los Angeles and Other Real-and-Imagined Places. Inspired by Lefebvre's theory mentioned above, Soja introduces the concept of Thirdspace in order to overthrow the dualism that has "confined how we make practical and theoretical sense of the world" (Soja, 1996, p. 5) and create a space in which both the material space and the spiritual space converge. Thanks to its openness and inclusiveness, Thirdspace opens a new perspective for literary analysis.

The paper, on the basis of Thirdspace theory proposed by Edward Soja, explores the three-dimensional spaces constructed in the novel in order to explore Etsuko's pursuit of identity. A Pale View of Hills presents a dichotomy between Firstspace and Secondspace in order to demonstrate the conflict between Eastern culture and Western culture and advocates building a Thirdspace in which heterogeneous cultures can coexist harmoniously.

\section{Etsuko’s Marginal Identity in Firstspace}

Firstspace tends to "privilege objectivity and materiality, and to aim toward a formal science of space” (Soja, 1996, p. 75). That is to say, Firstspace represents the material space in which humans exist. In the novel A Pale View of Hills, Kazuo Ishiguro presents a vivid description of post-WWII Japan in which Etsuko lives. To summarise the situation of Japan after the Second World War, "the world had a feeling of change about it" (Ishiguro, 1982, p. 2). There is no doubt that after the War, Japanese society undergoes great changes.

First, Nagasaki, the city where Etsuko lives, is reduced to ruins because of the War, and Japanese people are in the process of rebuilding their home. As Etsuko notices, "then the bomb had fallen and afterwards all that remained were charred ruins” (Ishiguro, 1982, pp. 2-3). The War has destructed the homeland of Japanese people, and in order to recover from the trauma caused by the War, they are committed to rebuilding the city so that "in time four concrete buildings had been erected” (Ishiguro, 1982, p. 3). It seems that as the city is being rebuilt, people's life gradually returns to the normal state.

Second, as Japanese society is characterised by a hybridity of Eastern culture and Western culture after the Second World War, a space that is composed of diverse cultural landscapes comes into being. After the War, as American authorities exercise their power over Japan, Japan becomes the colony of America to a certain extent. As a result, both Eastern culture and Western culture coexist in Japanese society. Estuko notices that "American soldiers were numerous as ever" (Ishiguro, 1982, p. 2) and that in each apartment, "the floors were tatami, the bathrooms and kitchens of a Western design” (Ishiguro, 1982, p. 3). Besides, as Ogata-san, Etsuko's father-in-law, points out, "they [the Americans] decided our schools would be like American schools, the 
children should learn what American children learn” (Ishiguro, 1982, p. 45). In addition, it is conceivable that Western culture influences people's mind, and as a result, there emerge contradictions between Eastern ideas and Western ones. Japanese society thus seems to have become a space where Western ideas struggle against Eastern ones. The idea of democracy has spread so widely that a man and his wife vote for different political parties, which is unimaginable in traditional Japanese society where a wife has to obey her husband. Shigeo Matsuda, one of Ogata-san's students, believes that something was wrong with Japanese education and even publishes an article in order to criticise Ogata-san's traditional pedagogy. As manifested by the two examples, Western ideas outweigh Eastern ones, and the reason for such a phenomenon lies in the hegemonic power exercised by America in post-WWII Japanese society. On the basis of the analysis, it goes without saying that diverse cultural landscapes come into being in Japan after the War, and the spatial practices creating the hybrid landscapes reveal America's power and central position.

Besides, private space also manifests the values held by those in power. Sachiko is forced to move from Tokyo to Nagasaki after the War and live together with her daughter Mariko in a sombre and dingy cottage, where "an old lantern Sachiko had lit provided the only source of light" (Ishiguro, 1982, p. 27). The cottage is characterised by "a kind of stark shabbiness" and "a faint odour of dampness" (Ishiguro, 1982, p. 8). Even she finds herself "in a difficult situation" (Ishiguro, 1982, p. 49). However, before moving in the cottage, Sachiko lived with her uncle in "a most beautiful house” (Ishiguro, 1982, p. 11). It can be supposed that without a man's support, Sachiko is in reduced circumstances and lives in the marginal space of the society. Sachiko's miserable private space manifests the males' power in Japanese society, and therefore Sachiko, as a woman living on her own, suffers marginalisation in the patriarchal society.

It seems that Etsuko also lives in a space where the male authority prevails. First, Etsuko would be homeless without Ogata-san's help. As a woman whose family was ruined during the War, Etsuko is taken in by Ogata-san, and as a result she is arranged to get married with Jiro, Ogata-san's son. As she asserts, “I really don't know where I'd be today if Ogata-san hadn't taken me in” (Ishiguro, 1982, p. 54). It is obvious that she is dependent on males in terms of her housing and marriage and fails to lead an independent life. Second, Etsuko, as a housewife, suffers her husband's indifference and rudeness at home. As narrated in the novel, having returned home after work, Jiro tends to read newspapers and never engages in conversation with Etsuko. It seems that there exists no love between Jiro and Etsuko. Besides, whenever Etsuko does something against Jiro's intention, Jiro will "give me an angry look” (Ishiguro, 1982, p. 42). The reason why he feels angry about Etsuko's behaviour is that he feels his male authority challenged by Etsuko's refusal to obey him. The detail manifests that Etsuko's home is actually a "phallic realm of (supposed) virility" (Lefebvre, 1991, p. 147), and it is conceivable that Etsuko is excluded from the centre of the patriarchal space.

As is manifested above, Japanese women are under the pressure exerted by the male authority in private space and serve as the other under the gaze of males. Therefore, they are excluded from the central space of the patriarchal society although "they form an integral part of the group, in which is governed by males and in which they have a subordinate place” (Beauvoir, 1956, p. 567). As Sachiko says, "Japan is no place for a girl. What can she look forward to here?” (Ishiguro, 1982, p. 126). Females are disciplined in the patriarchal society so that males can consolidate their authority, and therefore it is impossible for a woman to leave the periphery and build an independent identity in Japan. 
A Pale View of Hills presents a vivid view of Japan that is reduced to colonial space of America after the Second World War and also describes Sachiko's and Etsuko's private space. In Japanese society that is featured by a hybridity of Eastern culture and Western culture, Japanese women such as Sachiko and Etsuko are situated on the margin of the society. However, Sachiko and Etsuko refuse to situate themselves in the peripheral space of Japanese society and attempt to find an ideal space so as to build their own identity.

\section{Etsuko's Identity Crisis in Secondspace}

Secondspace is concentrated "on conceived rather than perceived space" (Soja, 1996, p. 78). It is "entirely ideational, made up of projections into the empirical world from conceived or imagined geographies” (Soja, 1996, p. 79). That is to say, Secondspace is "conceived in ideas about space” (Soja, 1996, p. 10). In the novel, the space conceived by Sachiko, or rather Etsuko, is an ideal country far from Japan, whether it is America or Britain. From her point of view, the foreign country that she conceives provides her with an opportunity to leave the marginal space and build an independent identity.

As analysed in the previous section, Japan, damaged by the War, becomes the colonial space of America, and therefore it is the periphery in comparison with America, which becomes the economic centre of the world after the War because it is "the only nation to emerge from the Second World War with its manufacturing plant intact and its economy strengthened" (Gray, 2004, p. 553). Compared with Japan, America, considered as "the society of abundance" (Gray, 2004, pp. 553-554), is undoubtedly a promising country in which people can fully exploit their potentials.

It is because of her inferiority and peripheral position in Japanese society that Sachiko, or rather Etsuko, conceives such an ideal foreign country where she can build an independent identity. It is noteworthy that Sachiko was encouraged by her father to learn English and acquire knowledge about American culture in her childhood, and considering America as an ideal country where everything seems possible for a female, she has always aspired to immigrate to America since then. From her point of view, it is by leaving Japan and immigrating to America that she can build an independent identity. It is fair to assert that she is unsatisfied with her life in Japan and thus conceives an ideal foreign country.

According to Sachiko, America is a place where she can successfully emancipate herself from the male authority. Yasuko, Sachiko's cousin, argues that “it isn't good that a woman should be without a man to guide her. Only harm can come of such a situation” (Ishiguro, 1982, p. 119). She hopes that Sachiko, who lives with her daughter Mariko, will live with her and her father. However, Sachiko thinks that "life is a little dull at my uncle's house” (Ishiguro, 1982, p. 80), thus making plans to immigrate to America. From her point of view, living in Japan means that she will have to submit to the male authority and remain on the margin of the patriarchal society, and only by immigration can she succeed in leaving the periphery in pursuit of a central space and thus build an independent identity so that she can be on an equal footing with males.

Besides, Sachiko regards America as a place where she can pursue a happy and decent life. As she imagines,

America is a better place for ayoung girl to grow up. Out there, she could do all kinds of things with her life. She could be a business girl. Or she could study painting at college becomean artist. All these things are much easier America, Etsuko. (Ishiguro, 1982, p. 140) 
From her perspective, as women are excluded from the central space in Japanese society, it is quite hard for a woman to gain independence, to say nothing of making achievements. The reason why a woman is situated on the periphery lies in "the fact that she is not permitted to do anything" (Beauvoir, 1956, p. 641). Therefore, if a woman aspires to be autonomous and move away from the periphery, she will have to pursue her own life. She expects to immigrate to a foreign country where everything seems favourable to females so that she can lead an independent life. Besides, America, as analysed before, is the central space in comparison with Japan. Immigrating to America means that Sachiko is eager to situate herself in a central space.

However, after immigrating to a foreign country, Etsuko fails to lead a happy life and build an independent identity as expected. First, her daughter Keiko, marginalised and isolated in Britain, commits suicide. There is no doubt that Keiko, unaccustomed to her life in Britain, locks herself in private space and cuts herself off from the outside world to a great extent. As Etsuko remarks, "Keiko had retreated into the bedroom, shutting us out of her life” (Ishiguro, 1982, p. 36). Even after she moves to Manchester, she still confines herself to her private space and refuses to communicate with the outside world. It seems that unaccustomed to her cultural identity in a foreign country, she chooses to construct an exclusive private space in order to struggle against the mainstream culture and conserve her original identity.

Second, as Britain is in fact an exclusive place, Japan serves as the other under the gaze of Britain, and therefore Etsuko fails to build her identity. For example, after Keiko’s suicide, many British newspapers put excessive emphasis upon the fact that she is pure Japanese because "the English are fond of their idea that our race has an instinct for suicide” (Ishiguro, 1982, p. 2). The example shows that British people are convinced of the stereotypical opinion about Japanese people, and it seems that British people view Japanese people from the perspective of Orientalism, which allows "Europeans to deal with and even to see Orientals as a phenomenon possessing regular characteristics” (Said, 2003, p. 42). Such a point of view expresses "the strength of the West and the Orient's weakness” (Said, 2003, p. 45) and thus makes a dichotomy between British people and Japanese people. In consideration of the fact that "no identity can ever exist by itself and without an array of opposites, negatives, oppositions" (Said, 1994, p. 52), it is reasonable to say that the reason why British people view Japanese people as the other is that they expect to emphasise their authority by marginalising the latter. Therefore, there is no doubt that after immigrating to a foreign country, Etsuko finds herself marginalised to a great extent because of her Japanese background and suffers an identity crisis.

To conclude, a foreign country, as Sachiko or Etsuko conceives, is a place where she can gain independence and leave the peripheral space. It is through the imagination of a foreign country that Sachiko or Etsuko attempts to build an independent identity. However, after immigration, she comes to realise that things are not as good as expected and still confronts an identity crisis.

\section{Etsuko's Construction of a Hybrid Identity in Thirdspace}

The previous sections demonstrate that Etsuko is marginalised and fails to build an independent identity in Firstspace and Secondspace, and it is because of the identity crisis that she endeavours to construct Thirdspace so as to pursue her identity.

There exists a binary opposition between Firstspace and Secondspace. Thirdspace, however, is "a space of radical openness, a context from which to build communities of resistance and renewal that cross the boundaries 
and double-cross the binaries" (Soja, 1996, p. 84). It seems that it is in her country house in Britain that Etsuko successfully constructs Thirdspace and thus builds her identity so as to deconstruct the Firstspace-Secondspace duality.

Thirdspace is central and peripheral, real and imagined, and Etsuko constructs her Thirdspace out of her country house. On the one hand, the country house seems to imply her marginalisation in British society. Taking into consideration some details of the novel, readers may come to the conclusion that Etsuko leads an isolated life. As Etsuko herself points out, "my country house and the quiet that surrounds it made her [Niki] restless" (Ishiguro, 1982, p. 1). Estuko's daughter, Niki, considers the surroundings of the country house sombre and gloomy, while Etsuko, at the end of the novel, asserts that she loves the quiet. The quiet surroundings manifest Etsuko's isolation from the outside world, and her love for such a quiet space represents Etsuko's willingness to be excluded from the mainstream society. It is obvious that Etsuko chooses to live on the margin of the mainstream society in Britain. On the other hand, however, the country house seems to link Etsuko with the central space of British society. "The country house is one of the most familiar symbols of the English national imaginary” (Terentowicz-Fotyga, 2015, p. 7), and there is no denying the fact that a country house is a typical symbol of British culture. As Etsuko herself says, “I always think it’s so truly like England out here” (Ishiguro, 1982, p. 136). Etsuko's country house, to a great extent, represents the dominant British culture, and it evokes her imagination about the central space of British society. The country house where Etsuko lives is both real and imagined, both central and peripheral, and it represents Thirdspace, in which Etsuko builds her identity.

In addition, Thirdspace is characterised by its openness to diverse cultures, and it "may open the way to conceptualizing an international culture, based [...] on the inscription and articulation of culture's hybridity" (Bhabha, 1994, p. 38). Situated in her country house, Etsuko builds a hybrid identity by recollecting the memories of the past. "The work of memory [...] reaches a state of reconciliation and catharsis when it is completed" (Teo, 2014, pp. 9-10). Etsuko recalls her life experiences back in Japan and comes to terms with her past. She regrets bringing Keiko to Britain and also expresses her nostalgia for Japan. Besides, she comes to accept her hybrid identity. Hybridity "involves the fusion of two hitherto relatively distinct forms, styles, or identities, cross-cultural contact” (Kraidy, 2005, p. 5). As readers can notice in the novel, Etsuko, as well as Sachiko, is actually a hybrid of two cultures. When in Japan, she aspired to immigrate to a foreign country and refused to accept her Japanese identity, as manifested by the detail that she refrains from refuting Niki's assertion that she once thought the old Japanese way was bad. She mimicked foreigners and spoke English fluently with an American woman, thus demonstrating her desire to build a Western identity. After Keiko's suicide, however, she grows aware that because of her Japanese identity, she has no alternative but to situate herself in the marginal space of British society and thus feels disillusioned about her vain attempts to build a British identity. Just like a baby who experiences the relationship between his own body and the environment around him when looking at his own reflection in the mirror, Etsuko begins to reflect upon her relationship with the outside world. She comes to realise that her identification with the other, the foreign country, is just illusory and imaginary. At the end of the novel, she frankly asserts that "it's not a bad thing at all, the old Japanese way" (Ishiguro, 1982, p. 136) and thus embraces her Japanese background. There is no doubt that she builds a hybrid identity by reconciling Japanese culture with Western culture so that the two cultures can coexist harmoniously and the borderline between them can be erased. Therefore, by situating herself in the in-between space of the two cultures, she 
accepts her hybrid identity and puts an end to the conflicts between Japanese culture and Western culture, thus deconstructing the margin and the centre and eliminating the dichotomy between Firstspace and Secondspace.

To conclude, faced with an identity crisis in Britain, Etsuko constructs out of her house a Thirdspace that is both central and peripheral and accepts her hybrid identity after recollecting the memories of the past. In constructing a Thirdspace, Etsuko successfully eliminates the dichotomy between the subordinate East and the dominant West and embraces her hybrid identity as an immigrant.

\section{Conclusion}

In the novel A Pale View of Hills, Kazuo Ishiguro creates two juxtaposed spaces, namely post-WWII Japan as Firstpace and an ideal foreign country as Secondspace, in order to present Etsuko's marginal position and her pursuit of identity. Etsuko lives on the margin of Japanese society, and in order to pursue a superior identity, she immigrates to Britain only to find that she is also excluded from the central space of the society. It is by constructing out of her house in Britain an inclusive Thirdspace that she embraces her hybrid identity and successfully makes two heterogeneous cultures coexist harmoniously. The construction of Thirdspace in the novel reveals Kazuo Ishiguro's concerns for the ethnic minority who attempts to integrate into the West while conserving its cultural identity. It seems that in order to integrate into the Western society and also conserve his cultural identity, an immigrant is supposed to construct a Thirdspace open to all cultures and make a negotiation between his own culture and Western culture.

\section{References}

Beauvoir, S. (1956). The second sex (H. M. Parshley, Trans.). London: Lowe and Brydone (Printers) Ltd.

Bhabha, H. (1994). The location of culture. London: Routledge.

Gray, R. (2004). A history of American literature. Malden: Blackwell Publishing.

Ishiguro, K. (1982). A pale view of hills. New York: Vintage International.

Kraidy, M. (2005). Hybridity, or the cultural logic of globalization. Philadelphia: Temple University Press.

Lefebvre, H. (1991). The production of space (D.Nicholson-Smith, Trans.). Oxford: Blackwell.

Matek, L. (2018). Narrating migration and trauma in Kazuo Ishiguro's A Pale View of Hills. Sciendo, (31), 129-146.

Molino, M. (2012). Traumatic memory and narrative isolation in Ishiguro's A Pale View of Hills. Critique, (53), 322-336.

Said, E. (1994). Culture and imperialism. New York: Vintage Books.

Said, E. (2003). Orientalism. London: Penguin Books.

Shaffer, B. (1998). Understanding Kazuo Ishiguro. Orangeburg: University of South Carolina Press.

Soja, E. (1996). Thirdspace: Journeys to Los Angeles and other real-and-imagined places. Cambridge: Blackwell Publishers.

Teng, A. Y. (2019). Ethical status and ethical choice in A Pale View of Hills. Journal of Beijing University of Aeronautics and Astronautics (Social Sciences Edition), (2), 122-126.

Teo, Y. (2014). Kazuo Ishiguro and memory. Hampshire: Palgrave Macmillan.

Terentowicz-Fotyga, U. (2015). Dreams, nightmares and empty signifiers: The English country house in the contemporary novel. Frankfurt: Peter Lang Edition.

Zheng, Y. J. (2019). War trauma writing and generational differences in A Pale View of Hills. Journal of Xiangtan University (Philosophy and Social Sciences), (5), 135-140. 